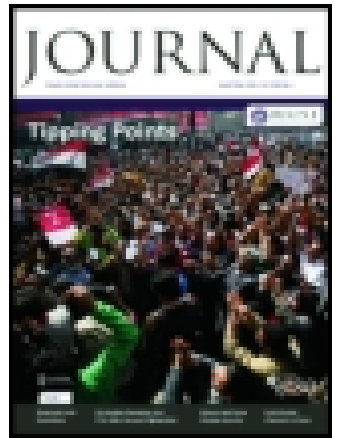

Royal United Services Institution. Journal

\title{
Corrosion and Fouling of the Bottoms of Iron and Steel Ships, and Means of Preventing the Same
}

\section{Charles F. Henwood N.A}

To cite this article: Charles F. Henwood N.A (1888) Corrosion and Fouling of the Bottoms of Iron and Steel Ships, and Means of Preventing the Same, Royal United Services Institution. Journal, 31:142, 919-936, DOI: 10.1080/03071848809416443

To link to this article: http://dx.doi.org/10.1080/03071848809416443

Published online: 11 Sep 2009.

Submit your article to this journal $\sqsubset$

Џll Article views: 4

Q View related articles $\sqsubset$ 


\section{athe}

\section{Bound änited Service ânstitution.}

VoL, XXXI. 1888 .

No. 142.

Friday, December 2, 1887.

REAr-ADstrRIL P. II. COI,OMB, Mromber of Conneil, in the Chair.

CORROSION AND FOULING OF THE BOTTOMS OF IRON AND STEFL SUIPS, AND MIEANS OF PREVENTING THE SAMIF.

\section{By Cinarles F. Hzwrood, N.A.}

Turs matter is of great national importance, both in relation to onr ships-of-war and our vast mercantilo marine, involving as it docs at the present time the annaal loss of handreds of thousands of pounds sterling.

Frer since the introduction of iron, and more recently of steel, in the construction of ships, corrosion has been and is an element of weakness and danger, moro particularly so in regard to steel-built ressels, in which the margin of thickness of the skin-plates is not so large as in iron.

It would appear from the early rules of Llosd's Committec, tho thickness of the plates for twelre Jears' iron ships was an eighth of an iach greater than for thoso of tho six years' grade. Tho experienco of the Committe, therefore, pointed to one-eighth of an inch as tho waste due to sir sears' corrosion. And the following experirnents mado by Dr. Calvert and Mr. Johnson aro interesting, although tho conditions under which they were made differ materially from the conditions pertaining to the actual life of iron and steel ships, and we the results from oxidation of both sides of the plates.

Loss of Weight per Month per Square Foot of Surface.

\begin{tabular}{|c|c|c|}
\hline & $\begin{array}{c}\text { In a resscl of sea- } \\
\text { rater. }\end{array}$ & In the sea. \\
\hline 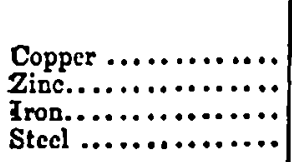 & $\begin{array}{c}\text { lb. } \\
0.0027 \\
0.0012 \\
0.0056 \\
0.0060\end{array}$ & $\begin{array}{c}\text { lb. } \\
0.0061 \\
0.0070 \\
0.0204 \\
0.0216\end{array}$ \\
\hline
\end{tabular}


The effect of zinc in protecting iron or stecl from oxidation bas been known for many jears past. When the tro metals are in contact, an electric or galranic relation is established between them, by which tho iron or steel ceases to be susceptible of corrosion by dilute acids, salino solutions, or atmospheric humidity.

Hero is a piece of bright iron, protected by zine on either side, which has been immersed first in a stiong solution of sulphuric acid, and for the last eight roontus in strong salt water; and you may obserro the iron remains bright, without any appenrance of rust; eren the nat and screw-bolt making the conncetion between the two metals is also completely protected from corrosion.

Marine boilers aro now protected on this principle, and witl tho most satisfactory results, as regards efficiency and cconomy.

In former times rooden ships bive been sheatlied with zinc, but more for the purpose of preserving them from senworms than from fouling; for in spite of the experiments of Dr. Calvert and MIr. Johnson, it was found that in case of wooden sbips, trentill-fustencel, a hard oxide was soon formed on the zine, to which barnacles and weeds adhered very firmly.

On the other land, on rooden ships, copper-fastened, the eine wasted awny in patches, the copper being electro-negative to rinc. No existing compositions renlly meat tho difficulty of fouling; no: is there much prospect of success in that direction, as neither smootl surface nor poisonous comprosition will becp off barnacles and other marine growths; and the only means of accomplishing this is by the oxidation and wasting array of the surface, which, in parting with n portion of itsclf, carries awns with it such parasites.

Within the last fow days, I lavo had placed in my hand a circula: of a Mr. E. Wood, "Manufacturing Chemist and Contractor to H.Mr. Board of Admiralty," adrertising his "Protectire aud Anti-fouling Compositions, fe., for the bottoms of iron, stecl and wooden ships," and which, lie states, is " $\Delta \mathrm{n}$ excellent preserratire to metal shealling, lessening wear and tear."

Ir. Wood remarls as follows in his circular:-"Coustantly is a ramour heard of the coming perfect anti-fouling, wntil at last thero is utter scepticism as to its possibility, and shipowners strear by tho latest specimen that, by some accident, they have been persnaded to accept, and generally without inquirs into the matter at all commensurate with its importance. I bill for a few hundred pounds spent on the hoilers or engines, in order to obtain a knot or two more of speed, is expected as a matter of conrse, and then the ressel is supplicd with some composition on the bottom, which neutralizes tho extrn power in the engine-room.

"But the anti-fouling ought only to be considered as coincident with the protection of the plates, for if the iron is not thoronghly protected from the sea-mater, or perchance of any composition that may be applied over the protective coatings, the very iron of the ship mas suffer. The requirements of the protectire coatings are then a 'thorough bite of the iron' and 'insolubility in.rrater.' 
- "Conpositions minj, broadly speaking, bo classificd into two divisions-the grease and the paint.

"Greases, such as tallow, and others sold under different denomi: nations, have been in general use, but with very moderate results. Their efficacy depends on tho gradanl falling away of the grease, aud with it the various attachments. 'T'he greases labour ander the gicat disadraritage of haring to be applied in a warm state, and; iu the opinion of many, of retarding the ressel.

"Tho Patent Office records show numcrons attrinpts on these clinging followers of the decp, in the shape of doses of arsenic, mercars, \&c.; but it is now generally thought that these substauces, poisonous to haman and other lifo when taken into the system, are not poisonous to the low order of sca-life, nor indecd do we know that they take the poison into their systems.

"It is better to pass over the wonderful nostrums recorded in some of theso patents, in which nearly crery article that can be mado up into the shape of a composition is included, in the appirent hope that, anongst the rariety of ingredients, something mas act. In some instances, thes hare come like a comet on the scenc, and, having scrved their pnrpose, have disappeared. And, indecd, it is casy to get a reputation for a good anti-fouling; giren a steamer which sails for a month or two straight ahesd, goes even into tropical waters, reposes in a clean or different water (such as a fresh water river, \&c.), and with a quick return to the dry dock, wo havo the data for showing frood results. Given also a royago at certain seasons of the jear, even in waters usually with a great tendency to fouling, and a clean bottom is the result. Given a vojage to certain ports that arc blessed with cool and clean water, and ne hare tho elcments of success for anj composition."

I may here quote the following, extracted from "A Manual of Naral Architecture," by the prescent Director of Naval Construction at the Admirnlts, pnblished in 1877. MIr. White writes:- "Varions plaris hare been tried for attaching zine sheathing to iron hulls; that more conmonly used in the Rojal Navs is as follows:-A single thickucss of planks (3 to 4 inches) is bolted outsicle the skin plating; to this tho zinc sheets are nailcd; tho strakes of planking are not. caulked, but the water which finds its way under the sheathing can pass freely through the scams to thic iron skin. Iron stems and stcinposts arc emplosed; and by rarious means a certaiu awount of metallic connection is made between tho rinc and the iron luull, such connection, as explained previously, being desirable in order to kecp the surface of the rinc free from incrustation."

Now, it will readily be secn that by this plan there exists no metallic contact whatorer; consequently uo clectric or galvanic action, or, if any, of the fecblest possible character. In addition to which there exists an insulating material between tho iron hull and zine sheathing, in the shape of tho rooden planks.

Other plans have becn proposed aud jatented, among which I may briefis describe those of Mr. Daft, Sir Nathaniel Barnaby, and MIr. Miclntyre. 
Mr. Daft's plan required that tho ship should be specially built, or at least that tho skin-plating of the ressel should be specially arranged; that is to say, the outside plating was to bo worked tlush with internal butt-straps at tho scams as well as the cods of the plates. $\Lambda$ space of about an inch in width was left around cach plate, forming when rivetted up a grooro into which compressed teak was to be plnced. The zine sheets were to be of about the sime size as the iron plates, and nailed with zinc nails to the compressed teak in the groores surrounding cach plate; and whero the plates were large, holes were to be drilled in tho centro part, where required, and plugged with com. pressed teak or ebonite to reccire zine uails. Hero the zinc sheets were to bo laid directly on to the iron plating, without any insulating matcrial between them; and so far a better plan than the above, jet tho necessity for special construction, and its great expense, were reasouablo objections to its adoption.

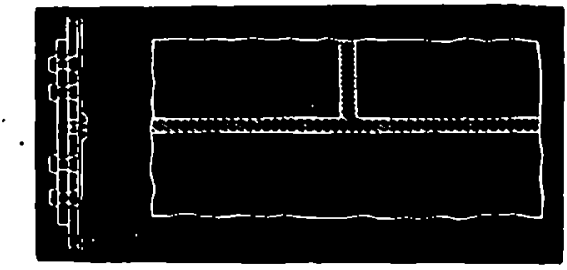

The plan of Sir Nathanicl Barnaby was more simplo than that of Mr. Daft. He required no special construction or armingement of the skin-plating, like Mr. Daft. Ho proposed to drill or form holes in the rivets, after the ressels were riretted up, nod fill such boles with a soft metal or other substance, and nail tho zinc sheets with zine nails into the soft metal or other substance. The simplicity of this plan of sheathing iron ships with zinc is apparent; but the risk attending the adoption of such a plan is also apparent.

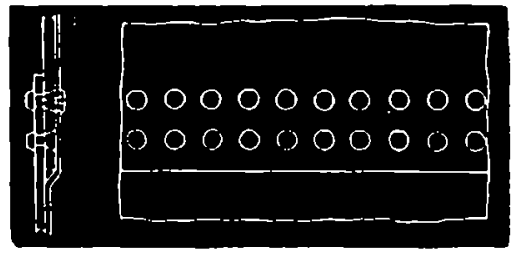

Mrr. McIntyre's plan consistcd of riretting galranized iron strips, with grooves to receive the edges of the zinc sheathing, to the ships' plating, the middle portions of the zinc plates being secured by similar strips, or screws, into the iron plates.

I understand a vessel was actually sheathed on this plan of Mr. MeIntyre, and proceeded to Australia, bat when she arrived at Australia tho whole of the zinc sheets had disappeared, not from 


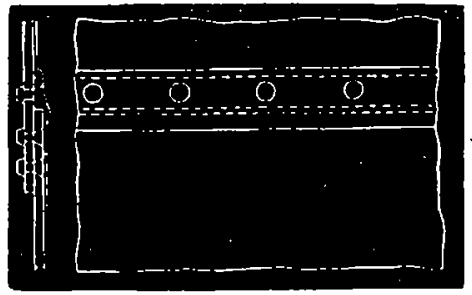

oxidation or wasting away, howerer, but from tho insecurity of the method of fasteuing tho zinc sheets to the iron hall.

In each of these plans for sheathing iron ships with zine sheathing, the main element of saccess is ranting; that is, contact betreen the two metals, the iron and the zinc, in order to establish complete galvanic action. The two metals, be it noted, mnst bo in contact, not their respective oxides, which alone obtains in the plans I have referred to.

"Hitherto," Mir. White writes in 1877, "the practical difficulty has been to adjust the relative amounts of the surfaces of iron and zinc, contributing to galvanic action on the latter, in such a manner as to prerent too rapid or too local wearing of the zinc, without interfering with its anti-fouling properties."

I presumo $\mathrm{Mr}$. White lad in his mind, when ho wroto this, the plan "commonly ased in the Rogal Nary," in which, as I have pointed out, no metallic contact exists, and as a natural consequence galvanic action fails.

However, Mr. White further wroto (just ten years since):- " Before many years the question will probably be in a mach moro settled condition; and although there is little hopo that zinc can erer bo made to equal copper in its anti-fouling qualities and smoothness of sarface, yet, if it be mado fairly successful in this respect, it will greatly redace the cost of construction, and the risks of accident or collision. Alreads it seems certain that a very great improvement upon the condition of unsheathed iron ships can be secured by tho use of zinc sheathing. At present, therefore, tho question of preventing foulness of bottom of iron ships stands as follows (1877):By far the greater number of ships have their bottoms coated with some anti-fouling composition, and aro docked for cleaning and recoating once or twice a yenr, when it is practicable, and no serious loss of speed cnsues. A few iron slips, designed for distant voyages, and in which the power of keeping the sea, without serious loss of speed during long periods, is of great importance, hare copper or zine sheathing. Copper can be mado to answer well as regards anti-fouling, but it involves a large additional outlay, and is open to the charge of possible damage to the iron hall in case of accident."

The plan commonly used in the Royal Navy was adopted on an ironclad belonging to the Brazilian Gorernment, and I am faroured by Sir Edward Reed, K.C.B., M.P., with the following account:- 


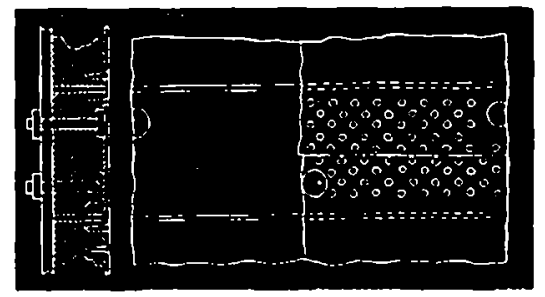

"The sheathing of the ironclad you refer to was composed of East India teak, of good quality, $2 \frac{1}{2}$ to 3 inches thick, excepting tho keel. which was of Einglish elm. The outer surface of the bottom plating was scraped and cleaned, and three conts of the best red lead wero applied, and the inside surface and edges of the planks woro corered with a thick coat of red lcad. The planking was not caulked, and was secured to the imn plating of the vessel with $\frac{3}{4}$-inch iron screw bolts, spaced about 2 feet apart, the holes in tho bottom plating to receire these bolts were very carefally tapped, and tho joints of tho bolts were further secnred by nuts, with a hemp grummet and washer on the inside. The bolts were made with a suitable slot in the head, and were hove up by a ratehet brace, observing that the heads were in all cases flush with the onter surface of the wood planks. The outer surface of the whole of the wood sheathing. was covercd with a thick coating of marino glue, and was further sheathed with. Veillo Moutagne zinc, about $\frac{1}{2} \frac{\text { th }}{6}$ of an inch thick, secured with $1 \frac{1}{4}$-inch zine nails.

"The wood and zinc sheathing extended from abont 2" fect below the load water-line on the ono side of tho ship, to a similar height on tho other, and at the upper edge the wood was snaped away, and the zinc sheathing brought over it and fastened to the armour plating by galranized tap scrers.

"The whole of this work was performed in June, 1875, and the ressel was in continuous service in South American waters, withont being docked from that date to September, 1885, when she was placed in a dry dock in England. During this time I beliere certain parts of the zine sheathing wero renewed by divers, but an examination of the stato of tho iron bottom in 1885 showed it to be in a remarkably good state of preservation, and requiring no attention whatever. The wood sheathing was also in a good state, and did not require renewal.

"Tho zine sheathing had wasted away considerably, moro especially in the region of the fastenings of the rood planking, showing conclusirely that the galvanic action set ap had acted as was originally intended, and that the plating of the ship was fully preserved.".

Now wo haro seen that, to obtain proper galvanic action, the tro metals must bo in contact.

It will be apparent also, and experiments prove it, that zinc slicets of the samo surface as the iron or steel will oxidize or wasto away uniformly and evenly, and not locally or in patches. 
It is found also, from experiments, that the wasto or osidation of tho zinc sheathing, whon in galranic contact with iron or stcel, is from the outer surface chiefly, and the oxidation : or waste is from 2 to $2 \frac{1}{2}$ ounces per square foot per anninm; that of copper on wooden ships being about 3 ounces per square foot per annum.

In tho plan I have now the pleasare of isubmitting to you for preventing corrosion and fouling of iron and steel ressels, the two Inctals, the electro-negatire iron or steel and the electro-positive zinc sheathing, are pliced and permanently fixed in contact; by which means an electric or galvanic relation is established between them.

There is no insulating matcrial placed between tho hull and the zine sheathing, which is fitted as closely as possible to the iron or stcel hall.

No holes are drilled into the iron or stecl hull, nor is any alteration of structure required.

The zinc sheathing is secured to the iron or steel hull by means of a zinc solder, which is less electro-positive to iron or steel than zinc itself, consequently will bo more enduring.

The attachments are mado at abont $l 2$ inches from centre to centre; and of such strength, that the sheathing may be torn off, learing portions still attached to tho solder, which also adheres firmly to tho iron or stecl.
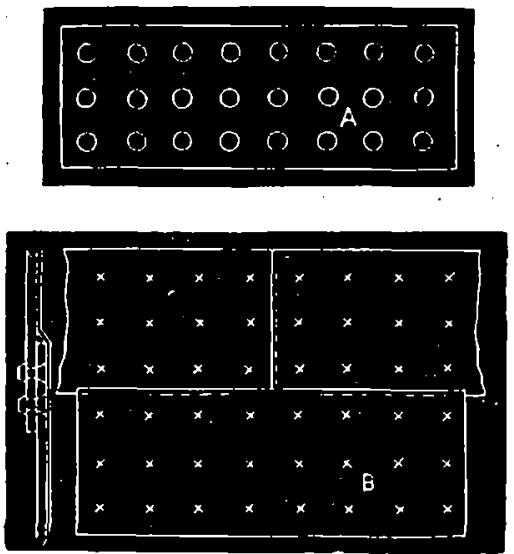

The zinc sheets are 8 feet long and 3 feet wide. A template is made of the size of the sheet zinc, with holes about fire-cighths of an inch in diameter, 12 inches from centro to centre, and 6 inches from the edges (Diagram A). The zinc sheet has similar holes punched in it, and around each holo a layer of zinc solder. is fixed, about 1 inch in width; also along the upper edge and after end. The sheet is now ready to be attached to the side or bottom of the iron or steel ship. The template is then applied to tho side of the ship where the sheathing is to be applied, and its position marked on tho ship, and tho position 
of the holes (Diagram B). At the position of these holes the oxide of iron or stecl is removed (with chisel and hammer or cmery wheel) for an area of about $2 \frac{1}{2}$ square inches, over which a lajer of zinc solder is fixed. This part of the ship is thus prepared to receire the sheet zinc similarly prepared, and when pat in place, the respectiro layers of zinc solder aro united with a hot soldering-bit, at tho seme time the hole in the sheet zinc is filled up flush, and the attachment is complete. - A practised hand can make about sirty attachments in an hour, and the largest ressel may thus bo sheathed with zinc in about a week or ten dajs.

To test galvanically the endurance of such attachments an experiment was mado by Professor Mosely, of the London University, who wrote as follows :-

"At your request I pnt on paper the result of an experiment mado by us with a view of testing the power of resisting corrosion of a com. bination of zinc solder and iron prepared by jou. You handed mo a small square of iron plate about 3 inches in the side and ono fifth of an inch in thickness, to either face of which wero attached by means of their centres with solder similar bat thinner plates of zinc. Theso plates of zino were closely applied to the two surfaces of the iron.

"This combination of metals was placed by us in a largo volume of a mixture of equal parts of commercial hydrochloric acid and water, which was allowed to act upon it for about a quarter of an hour.

"When the samplo specimon was withdrawn, it was found that the iron had not been corroded at all, and that the solder on both sides of the plate had, as far as could be detected, not been acted upon at all by the acid.

"The zinc, on the other hand, was nearly removed, a thin, imperfect. lamina only remaining on either face of the iron plate, still firmly held in position by the solder.

"I should infer that during prolonged exposure of a similar combination of metals in sea-water, all tho zinc would bo removed by corrosion before either the solder or iron would be attacked. It is important to note that the zinc has not, in the specimen referred to, been corroded most around the soldering point, but on the contrars, at its extremities."

This latter result is chiefly accounted for by the fact of the extremities not having had zinc protection.

With regard to the cost, I may mention that iron or steel ships may be sheathed with zinc sheathing on this plan at abont one-tentl of the cost of the plan commonly used in the Royal Nary.

At the I.N.A., in 1864, Mr. Lamport observed, and the like observation may be made at the present time:- "Some gentlemen made light of the question of fouling. I took up the 'Shipping Gazetto' the other day, and looked at all the ships orerduo finin China, tho longest arerage rojnge mo have. They were all of them erer six months on a royage, which is from tro to three months more than they ought to be."

A commander of the $P$. and $O$. Company obserred :- "I hare been in the habit of taking ont several iron steamers before to distant 
parts of tho world, conted with different compositions, but invarinbly found that their bottoms were fouled with weeds and burnacles before we had been six weeks at sea, much retarding the latter part of the rojage, notwithstanding we had taken opportanitics of scrubbing them off as far down as we could reach."

Tho late $\Lambda$ dmiral Fishbourno stated that when he wins on the const. of Africa, an iron whaler camo out from England; and though she had only left six months, and been cleaned as well as they could at sea with long brooms and ropes ander her bottom erery month, she had long grass and barnacles of immense size attached to her, in consequence of which she was not safe, as she would neither sail nor steer, and was not manageable.

Thic "Times" of 25 th January, 1865, reported that:- "The 'Royal Oak's' bottom was found to bo foul bejond all conception. Immense quantities of zooplygtes, reeds, and coralline flourished in the wildest profusion, and so liard had the little insects formed their habitation, that nothing short of a general scraping with short scrapers would remore the incrustation, the result of barely six montls' accumulation. IVbether this rapid growth is duo to the MLuntz metal with which the ship's bottom is sheathed, or the result of some general galranic action, is hard to conjecture." On tho other hand, the strmour-plating abore the sheathing was found to be caten awas into holes and groores balf an inch to five-eighths in depth. Somo of the plates contained no less than 188 of these, whilst noue bad less than forty. This corrosion nppeared to havo occurred whererer the paint lind been worn off.

The "Tines" of 3rd Norember, 1865, reported that:- "Tho condition of the 'Agincourt' at Deronport has created considerable surprise in the minds of the offeers of the dockyard and others. $A$ bout six weeks siuce she was remored from the Prince's Dock, after liaving been conted a second time with Iray's anti.fouling composition, and was placed alongside the sheer-hulk in Harnoaze, where she received her fivo iron masts, aud was otherwise prepared for preliminary trial of her engincs, which took place on the 12th ultimo. On Monday last the 'Agincourt' was replaced in Prince's Dock, and as the water was pamped out her bottom below tho line of lotation looked, as one of the artizans described it, 'like a ficld of grass,' so regular was the growth of tho weeds. Somo were nearly' 2 inches long, and it crtended from stern to stem and down to tho kecl."

'The I'rench ironclad "Invincible" had not been docked for ten nonths, and when docked, the copper sheathing was found corered with a thick mass of marine vegetation, a sort of white coral, and many hinds of shell fish formed a stratum which completely hid the sheathing, nnd was 5 centimetres or nearly 2 inches thick over certain parts. There wero also in certain places patches of ofsters, which fir.nly adhered to the shcathing. There wero not less than 10 tons of regetable matter or fouling removed from the bottom.

Just before being docked and cleaned, sho was tried under full steam, the weather boing calm and water smooth, when her greates specd was 9.8 knots with 51.5 rerolutions. After being docked and 
cleaned sho was again tried, when her speed was 13.2 knots with 53 revolutions.

Tho "Shipping and Mercantilo Gazette" of September Ist, 1865, records that tho "Ceglon" and "Poonnh" of the P. and O. Company were cach coated with a new composition, and the result was "unost extraordinars." Both ships havo returned after their first royage of a few wecks in sorry plight. 'I'ho "Ceylon," notwithstanding sho had been twice scrubbed nurond, in less than two montbs was found covered with grass from 12 to 18 inches long, and barnacles, zoophytes, sec, had begun to form all orer the bottom, so that she was delajed on her homeward royage several days. The "Poonah" was nearly" us bad after only six weeks' absence.

And the following case is of recent, and I might almost say, of daily occurrence :-

$\Lambda$ screw stenm vessel, with a carrying capacity of 3,500 tons dead weight, started on a vojage from England to Cape Town, loaded; from thence she procecded in ballast to Cocanada, and loaded for Liverpool via the Suez Canal. On the rojage out she indicated 947.06 horse-power, boiler pressure $70 \mathrm{lbs}$, speed 10 knots, and draught 23 feet on an even keel. On the rojage hume she indicated 970.96 horse-power, boiler pressure 80 lbs., speed 7 knots, and draught mcan 24 fect 2 inches ( 22 fect 9 inches forward and 25 feet 7 inches aft). As the small difference in her draught, taking also into con. sideration her trim, cannot be held accountable for a loss of thrce knots, thero is nothing else but the stato of her bottom to explain it. When placed in dry dock on arrival in England she looked exactly like a balf-tide rock, and four railwas-truck loads of barnacles and other zoophytes were removed from the dock. When cleaned sho again made 10 knots speed, with $76 \mathrm{lbs}$. pressure, and 9.17.06 indicated horse-power.

The extra resistance of the fouling unatter is plainly shown by the greater pressure on the boilers and greater horse-power.

The value of such a steamer may be reasonably taken at nboat 54 ?. per day. The loss of time due to fouling is eighteen days, thus making the total less on a voyage of four months 9722 ., without making allowance for the extra coals burnt.

'lo obtain 7 knots with a clcan bottom would not requiro more than about half the arnount of coal to obtain 10 knots; and taling the full consumption at, 24 tons a-day thero was a further luss of, say, 12 tons for 18 days, 216. tons at; say 30 shillings a ton, amounting to $324 l$, making a total loss of about $1,296 l$.

If such be the loss on one steamer luring a four montlus' royage, the loss on the numerous long voyage steamers nnd sailing ships must nmount to an enormous sum every jear.

"When one thinks" (romarks Admiral Paris) "u: the number of steamers on the seas, of the thousands of tons of coal they burn, one cannot help sceing that the wealth of the whole country is being spent in this obstacle; tho overcoming of which would produce enormous profits.".

In conclusion, the position of the matter at present is as follows :- 
Tine as a sheatling, eren as hitherto imperfectly applied, preserves iron or stecl from corrosion in sen-water; and in certain cases from fouling.

It mas, then, be fairly and reasonably assumed that zinc sheathing if applied so that the elcetro-positire zine is in contact with the electronegativo iron or steel, an electric or galsanic relation bcing thus established between them, the zinc would be perpetually dissolving away in an oxide, and carry with it the barnacles and other zoophytes, learing a clean surfuco; nud thus iron or stecl ships, so shenthed with zine, may navigato tho seas practically as freo from fouling as our old copper-sheathed rooden ships.

Thic Charrysx: This is a much moro iniportant subject than it generally looks, and I ain sure we eball be rerg glad to hear anjbods who can epeat with some knowledge or authority upon it.

Jr. Ji A RTELL (Llogd's): I did not purpose making any remarks on this paper. I came here to hear wkat Jir. Ien rood had to say, becuusc I think therc is a good deal of credit due to him for giring his uttention to this question, which is one of rers great inportanec to the mercantile snarinc. The principal reason why I nor wisls to speat is in reference to a statement mado by Mr. IIenwood, which I think, without some esplanation, rould be rather misleading. Mrr. Irenwool states that, judging from the rules of Llojd's Committee, they consider that there would be something like a deterioration of one-cightl of an inch in iron plates, or wasto by corrosion, in eix yeurs; that would be rery mislcading to go out to the public. 'The reason why Lloyd's rules wado differences in their seantlings for different classcs of ships was in order to cnable shipowners to build ships of ccrtain ecantling; that would suit tho particular requirements of their trade. A ship that wasintended for orer-sca rojage, or. for North Atlantic rogages with the roughest linds of enrgocs, evidently would require greater fesntlings than a ship engaged in cossting rorages, or shorter royages, or carrying lighter goods, and consequently it was necessary to lisy down diflierent seales of scantlings, to mect certain particular trades that orsecrs wished to build ships for, and still cnable them to obtain a class in Iloyd's Register Book. The number of jears nssigned to thoso was more for the purpose of requiring that at the end of that time those ships should liare a thorougli examination; that all parts should bo esposed in the inside, so as to bo perfectly certain as to the amount of detcrioration that had gone on; but to injply from that that Llogd's Renister Conmittec supposed that a resscl built of iron would deteriomte one-cighth of un inch in sir years would be perfectly misleading. The rules werc not framed at all on such an assumption as that. With reference to this general question of costing iron ships with zine, of course, as Jir. Ifentrood hins pointed out, sarious modes liave been adopted in order to accomplish this, and if sonething of the kind could be done by which the bottonis of iron ships miglat be protected frond deteriora. tion and fouling to a greater estent than they are at the present time, a most important desideratum would bo accomplisbed. Practical nen and clemists of the greatest experience liare deroted their altention to this, and I regret rers much to say that up to tho present time we haro not necomplished so nauch 39 is neccssurs, and 23 wo hope we shall be able to look forward to. But with reference to Mr. IIenwood's particular plan, I think it is to bo regretted that in this paper be las not ealled our attention to $\mathfrak{u}$ vessel where his plan hiss been specifically applied, and where I beliere, if $I$ an not ineorrect, it was dono under the special superrioion of Mr. Henwood himself. I alludo to the yacht "Dessie," iwhich I remeriber distinctls was so deslt with Eomething liko fise or six ycars ago in the Clyde. "Now in theso rcmarks I an maling, I trust Mr. Ifenwood will not think I and unduly criticizing his plans, but I merels wish to bring before tho audicuce and the public, if it will cowe befure tho public, in any was, thint here lias been the netual practical application of this plan that has been brouglit forward herc, to a sca-going ressel, and that conecquently mo sare somo rery great and specific experience with referenco to this, and I think this experience ought to bo placed before .11, in order to 
ensble us to judgo as to the practicability of applying this plan, and likerrise as to the efficiency of it after its application. It would bo rers intercsting if Mrr. IIenwood would tell us what experience has likewise been gained since that timo in other ressels; whether it has becn applied to any other ressscl, and if so, whether any better means hare been adopted for securing this zine on to tho bottom; whether he has more specific data to bring before us as to the eflicacy of this plan. In the sacht "Bcssic," where this plan was applied with the full cognizance and under the supcrsision of $\mathrm{I} r$. Ifenrood himself, quite in accordance with the plan pointed out lere, not a nere experinental plan in any war, but done in accordance with what MIr. IIenwood professes to be his particular plan-after slic lad been running something liko trelro montlss she was docked, and a large portion of this sheathing was found to be logt. A portion of it at the fore-part had been torn amaj, and tho water had got between the surface of the zinc and the iron, und liad burst through at the upper part in many places, forcing off the zinc at these parts. That only applies to the practical manner of at taching the zine. I think it is rery likels that that might be orercomc, and therefore I mould not condemn such a plan as this mercly becauso some diffeulty was found in keeping it perfectly secured to the bottom of a ressel. But there was something of far greater importance, and that was the actual principle of this application as to the effect which was cJaimed, and the initial purpose for which it was introduced, that is, the non-fouling of the bottom. Now the orner of this ressel found that, notwithstanding that this zine Fas attached in this manner to the bottom of this ressel continuously, not as MIr. Henwood eass as the Admiralty mas do it, here aud there, or in contact with the bottom at certain parts, but in actual contact throughout with the iron plate of the ressel. Notwithstanding that, this zinc was continually fouling, not occasionally, but continually; and they were brushing it orce continually, in order to get a clesn botton. When that ressel was put in dry dock, it was found that the grass had gromn on the bottom of that zine to the crtent of 3 fect in length. Now that is a rers important thing for Mr. Irenwood to explain to us. Mo says, that in two metals coming in contace in this way, the galranic action is found to take place crternally upon the surface of the iron, and that consequently sou would expect, and would hare in fact, exfolintion taking place on the cxternal surface of the zine, and that therefore any adhesire substance which might be on that would naturally drop away. But that was not found to be the case when it was actually tried on the ressel referred to. It has occurred to me that it is possible that when two metals are brought together, zine and iron, in this way, that where galranic action takes place, it would be more likely to take place on the inner surface of the zinc, instead of on the outer surface, bccause a large surfaco like a ressel's bottom, where the ressel ras passing through the ecas, would be rery differently affected from tro metals put in contact with each otber in a battery whero sou had a small quantity of rater, and the watcr might be thoroughly eaturated, so that the whole surface of the zinc might be affected on both sides. I am somewhat borne out in this by the actual result of the surres made by one of our surreyors, and which may be talen to be perfectly reliable, in which lie found that on the infernal surface there was a rery thick oride of zinc and salt, showing that there had been considerable galranic action going on between these two internal surfaces, but it was rery crident from the fact of those grasecs 3 fect in length adhering to the external surface, that there could not bare been anj exfoliation, or elso thes could not hare adbered se they did. I think it right to point this out, becauso it is a resy important matter, and we hare 80 inany anti-fouling compositions at tho present time that, as has been rery properly said by MIr. Ienwood, wo scarcels know where wo aro with reference to a great number of them, and if anything could be applied that would have a thoroughly anti-fouling effect, and I apprecinte it from rour point of riew as a naral Oficer with regard to men-of-war, that it would be a matter of rery greut consideration, and $I$ am sure, spealing for tho mercantile marine, it is a matter that all shipowners aro looking forward to, and that ko professional men are looking to constantly. We hope the time will arrive when we shall obtain something which will be an effectire protection against corrosion, and likewise against the foulings of the bottoms of iron and steel slips, but I fear that until we get either more experience or at least further explanation from MIr. Henwood, we cannat 
accept, at least I fecl that I cannot, his incre assertion that bis plen would bo effectire for this purpose.

The Cirarrisay: I ought to point out that in the discussion wo maj go by the title of the papes rather than the substance of it, because we hare really come here to discuss the rhole question of corrosion. If the paper had had another title we might hare been tied to the particular plan before us, but if gentlemen who speak will refer to the gencral question, I think it will bo better carrying out tho object plich the Council had in riew.

Mr. MARTELIs: If that is a sort of censure on the remarks that I hare made or the view that I hare taken, I feel, Sir, I must join issue with you on that point. This paper is as to the means of prerenting the corrosion of the bottoms of iron and steel ships, and here it is specifcally pointed out that there is one particular plan by which this might be effected, and I hare dealt with that particular plan.

'The Cin Insax : I think jou wero perfectly right. What crosscd mj mind was that you were restraining yourself to the particular points of the paper, which $I$ do not think, owing to tho title, it would be neceseary for other speakers to do, but sou were perfectly in order as far as you went.

$\Lambda$ dmiral Boys : I wigh to say just a fer kords, as a practical naral Offecr, bear. ing on the general question of the fouling of jron ships' bottoms, my object being to gire my experience as to the necessits and immense importance of keeping resscls under Nater as clean as possible. On taking command of the "Warrior," for her second coumission, in 1867, I had a correspondenco with her prerious Captain, Captain Cochrane, a man well known in the scientifie and naral world, rcspecting her qualitics, and he told me that he considered the loss of speed of the "Warrior," when going at what in thoso dass was thought to be high epecd, riz, from 10 to 12 knots, was approrimately 1 f knots after sbe had been sir months out of dock. My experience of her was the same. Fearly erery question connected with a slip. is inrolred, fighting efficiency, economy, consumption of coal, speed, and deteriora. tion of bottom. I mention this fact to point out the absolute necessity of more being done with this object, and possibly something in the direction which the lectures has indicated would haro the desired result.

Mr. IEE : I am here to represent Mr. Scrutton, but I did not intend to say anjthing upon the subject. I will not speak on the scientific question specially, but I hare becn connected with dry docks for many years, and hare had opportunities of eccing the condition of the bottoms of ship, and judging of the extent of the dete. rioration that has taken place. I hare known many ressels which hare been going to India and baci for unany Jears, contcd with tho present existing compositions, and really as far as the deterioration and the wasting of plates is concerned it has acemed to be almost imperceptible. Take for instance MIr. Joln Corry's ships, they are a rery good class of ships, well buile, and hare been coated with a raricty of compositions. One of these ships, "Star of Creece," made a rosage to India and back within six months, bcing as ehort a time as that in which very many copperbottowed ships would do that rosk. That may apply to ships going to Calcutta, but of course in eomo waters where ships are rery liable to foul, the bottom rould suffer rery much moro quickly. I do not know that I can Eaj further than that, but ray experience is that the deterioration in the iron is a rery slow process if the plates are vrell protected inside, and I hare known some ships that in trenty gears Lare only wasted to an almost imperceptible extent.

Mr. Lewrs : We haro all heard anti-fouling compositions called rers hard nnmes, and $I$ an conscious that I myself hare called them perhaps harder names than ulmost anyone; jet I confess it is rather startling when we are told of ships reing covered with coralline and masses of weed after a rosage of six reeks' duration, and those statenents being brought forward from isolated newspaper cuttings. I think if Mr. Inenwood had taken tho trouble to inspect ships of the Peninsular and Oriental, or any well-known line, when they come into dry dock after fairly long royages, he would not hare made the caso quite so atrong against present anti-fouling compositions. If he took any ships costed with one of the dozen best of these, I think he would find that the deterioration of the plates and also the fouling is not nenrly as bad as he anakes out, and that really these compositions haro a rers mucls longer life than ho supposes. What I nould epecially point out to you now is that 
we want to prolong the life of our compiositions, and not to bring out any more compositions or any more solemes which will only ecrre to protect and beep clean for a short time. We lase plenty of anti-fouling compositions in the market which will do their work in the mest admirable manner, for spaces of time extending with some, Tc mas safely say, up to ncarly nine monthe, and the great point which must be aimed at in anti-fouling compositions and protectires now is to find scliemes which will carrs on that period to a iater date, to protect a slip for fifteen months or two sears, instead of as at present, nine months. The question has entirely left tho ehort period phisc, because jou can absolutcly and perfectly protect your ships, and also keep them clean for periods under nine months. Now if you look nt the subject of sheathing slips with zine there are ecveral rery iniportant points which must be considered. In the first place, if $\mathbf{M} r$. Ifenmood will carefully esamine the zines in any form of battery he pleases, I think he will not be quite ns sure about the wasting of the zine taking place on the outside, and not on the side of the plate nearest the other metal, and as in the caso which Mr. Martell lias pointed out, there undoubtelly would bo a lorge amount of wasting of ziuc between the two metals. And secondly, if the zine plating is to keep off all fouling from the bottom, the extcrior surface of that zinc must exfoliate so rapidly, that is to s:ar jou must haro so strong a gulranic current, that instead of its being a prolongcil incthod of protecting a ship, tho plates mould be destrojed in four or fre months. Mfr. IIenwond gires some figures as to the rate of wasting of zine when in galranic contact with other metals, and I hope that in his reply he will tell us how those figures were obtained. IIe says, "it is found also fromesperiments tial, the waste or osidation of the zinc sleathing, when in contect with iron or stcel, is from the outer surface chielly, and the oxidation or wasto is from 2 to $2 \frac{1}{2}$ ounces per square foot per annum; that of copper ou wooden ships being about 3 ounces per square foot per annum." I sliould like to know the experiment by which those figures were determined, and under what conditions the zine wasted 21 ounces per square foot per annum, because you must remember that when you hare a large surface of zine in contact rith a large surface of iron, as in the boftom of a ship, you would, in the presenco of Eca-water, hare really a yery strong galranic current, and if that is strong enough to throw off the fouling from its outer surface bs a pruecss of solution of tho zinc, tlien I imagine that that zine would laro a rery short life indecd. There is another matter to be considered, and that is the expense. If you look at the rclatire amounts of waste in iron and zinc, jou will find that for every fifty-six parts by weight of iron sared from oxidation, you harc sixty-firc parts of zinc osidized, and I dare eas there are practical gentlemen present who can tell us comething about the relatire costs of iron and zinc. And not only do we hare this wasting of zine at the same rate, EaJ, that iron would waste, but we hare it wasted at an enormously quicker pace, on account of the galranic netion we hare set up by making perfect contact with the iron, and I think it is from these points that wo must look at IIr. IIenwood's proposition.

M. CARL LUGEST IlARTuAXs: I wish to ask if MIr. Henwood can give us any illes of the cost of placing his sheathing on iron ships. I will not discuss as to whether the methed is pricticablo or not, but cren if it is so, $i$ 'sems to me that it would be a great additionul cxpense in the building of ships; or in the casc of old ships it mould necessitate the same bein placed in dry dock for a rery long time, and, of course, would greatly aldd to the expense. If a ship is to be protected with zinc sheathing, I belicro it can only at the best be a surface protection. I jave scen many slipips coated with zinc sheatling that hare become rers foul after a comparatirely sliort period, and I can also corroborate what MIr. Lcwis has eaid as to the surface of the zinc being rery much impaired. It secms to me, therefore, that the zine itself will have to be coated with some composition, and it strikes me that if we are to lidre both tho zine and tho coating it will mean a rery scrious question of expense. I therefore think it would be well if he could gire us some idea as to what approsimatcly would be tho cost of putting zine sheathing on iron ships.

Afr. C. F. T. Yoosa, C.E.: It scens to bo imagincd that it is neccssary for a tremendous oxidizing power to bo npplied to the zine in order to keep it clean. 'That is not Eo; for so long as the surface is soluble the motion of the ship through 
the wator will kcep the surface clcan. The action is thus mechanical-it is a sort of chemico-mechanical action cxcreised on the outside of tho plate. One of tho speakers has alluded to zine shcuthing being more foul, but lie docs not tell us whether the ship was a rooden one or an iron one, because $I$ have seen a wooden ship slienthed with zinc as foul as anj iron ship has crer been. - It is a great mistake to think that copper keeps clean by being poisonous, it is simply because the surface oxidizes and keeps greas,, and the passago of the ship through tho water clearz the dirt off. In one case where the zinc sheathing on iron plate has been under water for twelre montlis, I found that it had oxidized rery equally and fairly. There is no doubt that the rate of oxidation will be increased by galranic contact with unprotected iron. I do not see myelf any particular difficulty in the matter. The only thing is it rants to be practically testel.' We all renember that when Sir IIenry Bessemer first proposed to blow cold air into hot iron to make it liotter ho was laughed at and called a fool, but I beliere the error was in not understanding the principle of the thing. I consider Jir. IIenwood's plan has solved the question of practical application.

Mr. Hrxwood: I will first reply to Mr. Martell's obserrations, and I may say I agree entirely with what he said, and perhaps I might, at the expense of lengthening my paper, have explained more fully about the thichness of plating and corrosion of iron ships. I quite agrec with what he said, bccause I lnon from my own experience that iron shipz may be practically called inperisbable. There is a rirer steamboat built forty-six years ago which was running the other day carrying passengers, and is still ecrriccable. It was not with that object $I$ introduced the subject, it was merely as an indication of former ideas. Of course there was nothing stated in the early Register of Ilogd's as the ground of this difference, and it was really left to the imagination to surmiso tho resson. I bnow further experience slows that iron ehips will last an indefinile period. Now I did not refer to the matter of the " Hessic," and I did not refer to it on this account, because it is not identical with that which I hare yow introduced to you. The "Bessie" was the first es. periment I made to slieathe a suall ressel with zine sheat hing directly on the iron.

The Cinamsex : Ilow long was that ago?

Mr. Hrxwood: Tho spring of 18S1. I could not possibly get the men to work this zine solder. I tried them in the laboratory, but could not get them to do it with their usual appliances for soldering, and a fricrid of mine who was interested with me in the matter suggested that we should fasten it on $\pi$ ith common solder. Kather than not hare the trial, and not haring mode the experiments which I hare sinco done, $I$ assented to its being so done. Now common solder is not of the satwe chameter as zins solder. It acts in the first place as an insulating material, so that thero was no galranic contact between the zine sheathing and the iron plating. On the other liand, I discovered after some time, especially in this ship, that wo could not malic sound conncetions witl common solder, and this will be casily understood, cepecially by Mr. JIartell; who bnows, as I doubt not, that common solder directly it gets to the melting point runs, so that when the heat was applied to tlic solder it mostly ran dorrn, and we only got a rery slight attachment round the lioles of the zine sheets, not more than in some cases one-sixteenth of ar inch. All along the edge of the water-line, although it looked pretty fair, when it was taken off it was found that there was practically rery little attachment, in fact, if the next das or the dasy afier I liad applied the redge test as I hare done to this specimen, $I$ should hare pulled the whole sheathing off, so feebly was it at tached, and it was probably bept so long as it was in its position from not being exposed to rough seas. "The "Bessic" was only employed about the mouth of the Clyde. The Captain wrote to me that during the first portion of the time, about six months, the zizc on the outside was always of a grensy nature, and that putting lis hand on it under water it had moro the fecling of a lire fish than anything else. Jut there being no galranic contact between the iron and the zine, it can easily be understood how it was that after some nine or ten months she began to foul, arid she did foul in the same ray as ships that I hare eecn in the Gorernment lockyards. Ships with the zine sheathing fastened on to the wood lining on coming back to England hare been rers foul indecd. I think this cxplanation will auswer Mr. Martell by showing him that the attachments on the "Bessic" wero rery 
different to theso attachments. This zine solder will not "run" lito common solder, sad you can make the attachments perfectly sound and strong crerywhero like this specimen. 'There ka another ressel similarls slicatbed, but not with my sanction. The late Mr. William I) shenthed, and he liked the ides $s 0$ much, he said he rould hare his ressel sheathed, but I found out by that time that it was uscless trying to makc sound and strong aftachments will coumon solder. It wat, hокетсr, done by my then partner vithout my knorledgo or conacnt. Tho "Bessic" met with an accident about thrce months after she was sheathed with zinc. Sho ras going at full epeed, and ran at about 10 knots on to a rock; sho lnocked her stem a ras and bulged her iron plates. She camo back, and after her iron bow nas repaired, I re-slicathed tho new plating as before. The iron hull was perfectly corered with rn iuside of zine, and there was no trace of corrosion, but tho zine sheathing itself did not appear to lare wasted sway at all, and apparently not at all on the inside. It is the same in theso laboratory experiments, and if jou look at them you will ece tho inside of the zinc practically is not touched.

Mr. MLARTEL: Is that dono in salt water?

Mr. IIEXwOOD: No, in a strong solution of sulphuric acid, but the same occurred in tho "Bessie." Tho cflect on the zine inside did not nppear so great as on the outside. Of courso during those fer munths tho deprecintion of the zine was vers small indeed, in fact it ras inepprccisble. The question of fouling is answered by the fact that there ras no proper galranic action betreen!the two metals in the case of the "Bessie;" that shows, if thero is no galranic coutnet betwecn the tro metals, and consequently no galranic action, tho fouling will tako place just the same as it docs in the cases of resels of the Koysl Nary glucathed with zine over the wood lining where the zinc fouls almost if not quite as readily as on a wooden ship.

The Cmanuss: What cxperiments are there to abow that if the galranic action were perfect, there rould not be fouling?

3Ir. If exwood : Only laborators esperiments. There were, homerer, some experiments, I think in reference to Mr. Daft's plan, made under the sunction of tha Admiralty in Portsmouth Docksard. I loped MIr. Young 'would hare told us about that. Also a shect of zinc and iron were secured on Mr. Daft's plan, and pul down at Shocburgness, and wore there I bclicre some twelre nnonthg, but being in a quisscent state, tlie zinc was corcred with a slimy substance which, howercr, could cagily be rubbed off by the hand, learing a perfectly clcan zinc beneath. If that aluect of zinc wlich was cxposed at Shoeburgness had been on tho bottom of a sbip passing through the rater, there would hare been the friction of the water to lere remored this accumulation, so that the zine would, by that mechanical operation, harc cxhibited a clean' surface, and it was from such experiments and others I obtained the data that tho oxidation was at the rate of from 2 to 21 ounces per square foot per annum.

Mr. LEwis : Is not the water at Shoeburgress brackish water?

Mr. II Exwood : I should think rery galt water.

Ir. I,EwIs: I thinl a ship conted with zine, tho "Audacious," which mas guard-slip at Irull for somo little timo under rery much the same circumstances, almost as zenr the eea, and in this brackish water no fouling or oxidation took ploce whatercr, and it ras thought the whole question had been settled. She was again conted rith zinc and sent to sea; and the zinc plates $I$ beliere were rers much acted upon, and the portions left were rery foul, showing that experiments in brackish water at tho mouths of rirers are not to be relied on as giring anytling libo normal results.

MIr. IExkood: 'I'his specinca at Shocburynces nas not perfectly clcan; it was corered with some elight accumulation, and it was only when that was remored, which could casily be dono by land, that the elean zine was exhibited bonesth, so that it could not havo becn under aimilar conditions to those mentioned in the north. The only other question I think was, as to tho cost and timo it would rake. Tho cost at present, without specinl sppliances, is sbout 10s. per squarc Jard, and the largest bhip might bo sheathed on this plan in from seren to ton days.'

1 About four months after the " Reasie" was sheathed, the Captain wroto me as 
Tho Cirsirursx: Gentlemen, I am sure we shall all accord a heart.5 rote of thanks to the lecturer for his interesting paper, but before asking you to do so it is usual for the Chairman to meke one or two remarks, and I suppose that, as I rns last year Chairman of an dumiralty Committec on this subject, I might be expected to $53 y$ something. I nislt the paper lide becn reid last year, because I was then hot on the subject, rery hot, and I could have said, I think, something that would hare been useful. Noir, with the number of other matters that hare come before me since, I am not so clear as I was twelre montbs ngo, but still there are one or two points which are rery prominently before me. I rentured to interrupt $\mathrm{M}$ r. Inenwood in his reply to put that question to him, where were the data to show that if the galvanic action was strong, good, and complete, there would not be fouling? As far as we liare got you lare observed the data are not rerg strong. I all not aware mysclf of uns uccurate comparative experiments erer haring been tried, where in the one case there was complete galvaric action, and in the other ca:c, under preciscls similar circumstances, there was not. It seems to me, before other experiments are tricd, that point ought to be established. Ity experience of fouling from the rers first days when I came to consider it was that where the galrunic action was ostensibly strongest, the fouliug was greatest. In paddle. whecl steamers, with coppor elacathing, which were the first slips I ecrued in, the fouling was always greatest in the wate of the paldle-wheels, and I rather assumed from that that there mas be some special attraction to marine growths in galranic action, and that then when they once get a grip, that they stop the exfoliation altogether. In the "Andacious," where I served for more than three Jears, I thought some of the strongest language I hare erer thought in my life. I hope I did not cxpress it, but I thought it on this rery question of the cnormous quantity of fouling that went on with zine shealling. I scrersaw aurthing like it. I nerer bnew any kind of bottom foul so rapidly or to such an extent as on that zine slecathing of IIer Mnjests's ship “Audacious." Of course the answer is made by the lecturer, that if the galranic action hal been complete, fouling would not hare taken place. 13ut the only proof that you can adduce on that head would be, was the iron of the ship attacled? Because it is natural to suppose if the galranic nction was not complete it would hatro shown itsclf on the iron. Now the iron was like rirgin irou when the zine sheathing was taken off in places, not $n$ sign of corresion. The zine plates were continually wesring awn, and, therefore, crfoliation of some lind was going on. 'Thesc are fact which have been before me, and seem to me to bear very much upon the question. 13ut, I think, as far as anti-corrosion gocs, tho zine sheathing, howerer applicd, is a complete remedy. I3ut then I do not think that at the present moment (I follow MIr. Lewis) the currosion is so important a matter as the fouling. The fouling is before us constantly. It was the great trouble of our forefathers in the last century. I think almost the grcatest troublo they had. Tho cry for clean ships, the difieulty of kecping up blockade owing to rapid fouling of ships before the inrention of copper sheathing, fills the oflicial letters up to the close of list century. Now the result of that wes the blockading squadrons were continually weakened by elip3 being sent home to be "eleaned and tallowed," as the phrise went. And as we stand at present, so far as I know, wo should hare to conduct our blockading in precisely the sane was. Whilo the cneny inside his ports would always hare clean ships, being closo to their docks, we on the outside would have ships that mere fouling rery rapidly after a time, and would hare to be sent home continually to be cleased

follows :- "The zinc on 'Bessic' does not yet show any signs of corrosion or fouling, while the buoy to which she is woorel, and which lins ouly been thirts-four days in the watcr, lias a gronth of buby burnacles on it alreals, besides a glutts cort of reed at least a couple of inches long; but then the buos is of wood, costed with red-lead. As far as appearances go at present, the rine sheathing looks like a success; in fact, if it continues to act as it seems 10 do at present, the succes 3 is a certainty. It looks extremely well without the patchy blotched appearance of paint, besides giring a perfectly smooth surface, much smoother than any sort of fuint or enamel that I hare secn tricl."

ror, XXXI.- 
just as they mere in the middlo and end of the last century. That of course would ecriously weaken erery blockading equadron, and would necessitnte our proriding at this present moment a greater number of ships for blockading pur. poses than would be recessary wero we certain that tlicir bottoms would not foul. 'That slows what a rery important subject this is from the Rosal Naral point of rier. I had a letter only tho day before sesterday from the orrner of the "Golatca," the yacht which raced last yeur for the American Cup, and he pointed out that this qucstion of the method of coating the bottom bad a grenl deal to do with the raciug trouble; and if something could be found which was absolutely smooth and would not foul, they would bo rery much better off than they are at present. These are the two plans only for anti-fuuling before us, the plan of cxio. liation, which has been adrerted to to-das, and the plan of poisoning. So little is bnown about the enbject that it is, I belicre, almost impossible to sas as yet how much the poison has to do with it, or how much exfoliation excrciscs its function in cases where manufacturers belicre in the one or the other: Mr. Lewis put the case precisels. We want to extend tho time. As he said, ans of the good compositions will last for screral montls, as much as nine ulonths in cases. Thiat means that the ehip will be in a fair condition for nine months, but then it rery much depends upon the water she is in, her motion through it, the senson, and 2 number of things that we kuow rery little about. These secm to ulfect the fouling, and soructimes under apparently precisely the same conditions, you get totully opposite results in the fouling. The eum of it to $\mathrm{my}$ mind is, that we should look to compositions more than to any systew of sheathing, that at prescnt we are moro likely to get on a sound basis in that way; but the inquiry must be made ecicntifically. The facts are not known; nobody really knows rery much about it cither way. I was only sorry that tho mones ran so short that our Committce could not go on sitting, because we were attaching the subject in a waj that had already giren us results, and we were bound to hive got more results, becnuse with tho aid of MIr. Lewis for chemical matters, and wilh the aid of the naturalists of the British Museum for the aniwal and regetable growtlis, wo were gradually coming to sce certain laws that were evolring thenselres ont of our method of procecding, and if we had been able to go on, I think we should hare got still moro lars and hare been able to bare laid down for the guidance of manufucturers some definite data on which they might hare worked, with the hope of getting ultimately to the bottom of the whole question. As it stand, the experiments are isolated, not classificd. Nobods realls linows what the true results aro or the causcs of those results, and it is only by mectings like thesc, where rcal attention is drawn to the subject, that we may hope that it may be talen up in a scientifie $\pi 25$ and ultimatels eolred. I hare much plesure in asking sou to accord a cordial rote of thanks to MIr. Henrood for his lecture. 